\title{
Study on Manipulation of Cash Flow from Operation in IPO Company _Evidence from Chinese A-share Market
}

\author{
Chi Zhaonian, Gan Shengdao \\ Business School of Sichuan University, Chengdu, Sichuan Province, 610064, China \\ chizhaonian@163.com, ganshengdao@scu.edu.cn
}

\begin{abstract}
This paper adopts Roychowdhury's models of predicting the cash flow from operation(CFO), takes IPO Company in 2002-2011 year as the study sample, and carries out empirical study on the manipulation of CFO in IPO Company 1 year before issue year, issue year and 1 year after issue year. This paper finds that IPO Company has the remarkable upward CFO manipulation in the 1 year before issue year, and the degree of manipulation will notably drop later; When the motivations of manipulation of CFO is further examined, it can be found that IPO Company that manipulate the CFO is mainly to enhance the quality of earning so as to cover Earning Management.
\end{abstract}

Index Terms - IPO, CFO, Manipulation, Match motivation, Supervision motivation

\section{Introduction}

The Chinese capital market is established since more than 20 years, and there is always a strange phenomenon that is: High IPO Price $\rightarrow$ Price falling down, and breaking issue price $\rightarrow$ Financial Achievement going bad. Many scholars think that this phenomenon is related to IPO issuing mechanism and the reality of China, and of course, excessive earning management is one of the reasons. Because the sensitiveness of earning information to the share market and the big manipulation space of the figure, earning management become the general phenomenon in stock market in China. In 1998, Accounting Standard-Cash Flow Statement was put into force, and more and more investors and other stakeholders paid close attention to the cash flow statement; the policy maker also paid the prompt and essential concern to cash flow information too. The supervisory systems are not only concerned about the earning information, but also the cash flow information. Gradually, this will inevitably attract the IPO company put more attention to the cash flow information.

Then we put forward such two questions: (1) Does IPO Company manipulate the cash flow from operation? (2) What is the motivation of manipulating the cash flow from operation for the IPO Company?

\section{Relation to Prior Research}

At the beginning, the scholar did not research the manipulation of cash flow from operation directly; they just found that the earning management involved manipulation of cash flow from operation when they studied the earning management. Burgstahler and Dichev (1997) found evidence that two components of earnings, cash flow from operations and changes in working capital, were used to achieve increases in earnings. Roychowdhury (2006) found that the company carried on the earning management in order to achieve the goal of avoiding losing through real activities, while the real activities did not only influence the earning information but also the information of cash flow from operation. Zheng, etc. (2003) studied the manipulation of CFO directly, and he found that the motivation of manipulation of CFO might be getting positive cash flow and matching the analysts' expectation.

In contrast with foreign scholar, Chinese scholars have carried many researches on manipulation of CFO in many aspects, such as the existence of manipulation of CFO, motivation of CFO manipulation, etc. Wang Xiao (2003) found that in 2002 the SEO Company witnessed a falling of $\mathrm{CFO}$; one of the reasons is manipulation of $\mathrm{CFO}$ by the management. Chen $\mathrm{Li}$ (2006) found that manipulation over operational cash flow was still the common practice in A share market of China. Wu Liansheng, etc. (2007) found that listed companies in China did manage cash flow to avoid reporting negative cash flow from 1998 to 2004. On the whole, there are $5.67 \%$ companies that engaged in cash flow management, and the average magnitude of cash flow management is 0.0043 .

\section{Analyses and Assumptions}

Since the cash flow statement standard was put into force in 1998, many researchers have started to study the information content of cash flow statement. The positive analysis of Wang(2003) showed that the cash-predicting models with cash-flow tables were more powerful, and revealed cash-flow information that was useful for investors to predict future cash flows. Since cash flow information can add information to earning information, the IPO company has extremely strong motivation to manipulate CFO information.

Manipulating CFO also has its possibility. We know that management can manage CFO through management of the credit and debt, etc.; finally, the real activities manipulation can also influence the CFO. All these methods of manipulation CFO can't generally be used continuously in several fiscal years. Therefore, these methods can only cause CFO to improve in a short time of a certain fiscal year, so this text proposes the first hypotheses:

H1: There is an obvious upward CFO manipulation in the IPO Company 1 year before the IPO year, and drops in the IPO year and 1 year after it significantly. 
In the stock market of China, profit is everything, so the earning management of IPO is a common phenomenon. But at the beginning, many earning management is through the nonrecurring profit and loss. The SEC of China put more attention to the non-recurring profit and loss after some company frauds exposure.

It is known that profits have two factors: the accruals and $\mathrm{CFO}$, if the company want to carry out earning management, he can manipulate the accruals or manipulate the CFO. If management manipulates the profit through the accrued project, then it will inevitably cause the decline of profit quality. Therefore, the company has the motivation to manipulating the CFO to raising the quality of the profit. Thus, we get the second hypotheses:

$\mathrm{H} 2$ : IPO Company has the motivation to match with the profit by manipulating the $\mathrm{CFO}$, in order to conceal the earning management behavior of the company, we call that the motivation is matching motivation (Abbr: $\mathrm{PB}$ ).

In 2001, the SEC of China issued two files with relation to IPO, and the files required that the supervisory body should consider the IPO company's CFO per share; On May 17, 2006, the SEC of China issued a new file, and required that besides regulation to accounting surplus information, the cash flow from operation in the recent 3 years must exceed 50 million. Because of these policies and regulations, IPO Company which does not get that line, will manipulate the CFO in order to increase rate of IPO review, so this paper proposes the third hypotheses:

H3: From the year 2006, the management has the motivation to manipulate the CFO in order to meet the policy requirements (Abbr: Year2006).

\section{Study Designing and Sample Selecting}

\section{A. Study Approach}

We divided the CFO into two parties: normal CFO and abnormal $\mathrm{CFO}$, if we can forecast the normal CFO, then, we can compute the abnormal $\mathrm{CFO}$ by such formula as this:

Abnormal $\mathrm{CFO}=$ Actual CFO-forecast normal $\mathrm{CFO}$

The key question is: How to forecast the normal CFO?

Roychowdhury (2006) used the DKW model for reference when he studied the earning management through real activities, and held the opinion that: the CFO is the linear equation of Sales and its increment. And through the linear regression, he calculated the coefficient of the equation, and forecast the future CFO by taking the coefficient back to the equation. The model of Roychowdhury is as Eq. 1:

$$
C F O_{i t} / A_{i t-1}=\beta_{0}+\beta_{1}\left(\mathrm{~S}_{\mathrm{it}} / \mathrm{A}_{\mathrm{it}-1}\right)+\beta_{2}\left(\triangle \mathrm{S}_{\mathrm{it}} / \mathrm{A}_{\mathrm{it}-1}\right)+\varepsilon_{i t}
$$

And the abnormal CFO can be forecast by the Eq. 2:

$$
A C F O_{i t}=C F O_{i t} / A_{i t-1}-\left[\beta_{0}+\beta_{1}\left(\mathrm{~S}_{\mathrm{it}} / \mathrm{A}_{\mathrm{it}-1}\right)+\beta_{2}\left(\triangle \mathrm{S}_{\mathrm{it}} / \mathrm{A}_{\mathrm{it}-1}\right)\right]
$$

CFO it means the actual CFO of i company in t year; Sit means the current Sales of $i$ company in $t$ year; $\Delta$ Sit means the increment of sales of i company in t year; ACFOit means the abnormal CFO of $\mathrm{i}$ company in $\mathrm{t}$ year; and the $\beta 0, \beta 1, \beta 2$ is the regression coefficient.

\section{B. Sample Selecting}

\section{1) Sample Selecting for Linear Regression}

The financial data that this text uses comes from 2012 CSMAR's financial database of listed company, deleting the company belong to bank and same institutes, we divided the remain company into 12 industries. In order to guarantee that each trade has enough sample company, we have collected the financial data of the sample company from 2000 to 2011.

The financial data that this text uses comes from 2012 CSMAR's financial database of listed company, deleting the company belong to bank and same institutes, we divided the remain company into 12 industries. In order to guarantee that each trade has enough sample company, we have collected the financial data of the sample company from 2000 to 2011.

\section{2) Selecting Studying Samples}

In order to study the manipulation of CFO in the IPO companies, we take the IPO Company from 2002 to 2010 as the study samples, in total, 696 IPO companies. For each IPO company, we select its financial data before the issuing year, issuing year and after the issuing year as the study data. The specific distribution of IPO company in each year as table 1 .

Table 1: The distribution of IPO Company in each year

\begin{tabular}{|c|c|c|c|c|c|c|c|c|c|c|}
\hline $\begin{array}{c}\text { Time of } \\
\text { IPO }\end{array}$ & 2002 & 2003 & 2004 & 2005 & 2006 & 2007 & 2008 & 2009 & 2010 & Total \\
\hline $\begin{array}{c}\text { Quantity } \\
\text { of IPO } \\
\text { Company }\end{array}$ & 58 & 58 & 93 & 12 & 65 & 96 & 72 & 60 & 182 & 696 \\
\hline
\end{tabular}

\section{The Variable Design}

Dependent variable: We choose the abnormal $\mathrm{CFO}$ as the dependent variable (ABBR: $\mathrm{ACFO}$ ), use the assets of opening balance as deflator to control the scale influence.

Independent variable: (1) Definition of matching motivation (ABBR: PB). The management may carry out CFO manipulating to conceal the earning management by improving the quality of the profit, i.e., CFO per Profit. We use the "CFO per Profit" of the company to be divided by the median of the industry's "CFO per Profit"; If the result is greater than 1, then $\mathrm{PB}=1$; other situations, $\mathrm{PB}=0$. (2) Definition supervising motivation (ABBR: Year2006). Because the policy maker gives detail regulation in CFO in the year 2006, so, we think the management will have strong motivation to manipulate the CFO from 2006. When the issuing year is in the year of 2006 of after the year, then the Year2006=1, other situations, Year2006=0. (3) PB * Year2006. We use the "PB * Year2006" to express the interactive influence between the "PB" and "Year2006".

Control variables: Because many factors can influence the CFO of the company, so we introduce 4 control variables to the model: (1) ROA, means return from the assets. (2) GRO, mean the speed of the assets increase. (3) DTA, means the 
Assets Liabilities Ratio. (4) LnA, mean the scale of the company.

\section{The Model}

We use the Eq. 3 to carry out the empirical test to assumption 2 and assumption 3. The financial data we use is one year before the issuing year.

$$
A C F O=\alpha_{0}+\alpha_{1} \mathrm{~PB}+\alpha_{2} \text { Year2006 }+\alpha_{3}(\mathrm{~PB} * \text { Year2006 })+\alpha_{4}
$$$$
\mathrm{ROA}+\alpha_{5} \mathrm{GRO}+\alpha_{6} \mathrm{DTA}+\alpha_{7} \mathrm{LnA}
$$

\section{Results of the Empirical Test and Analysis}

\section{A. Descriptive Statistics and Paired Samples T Test for CFO Manipulating Degree}

Describing statistics for CFO Manipulating Degree are as table 2 shows, among them, T-1 means one year before IPO issuing, $\mathrm{T}$ means IPO issuing year , $\mathrm{T}+1$ means one year after IPO issuing. As it shows from table 2, one year before IPO issuing, the degree of CFO manipulation is very high, and achieves 0.097 in mean value, Equivalent to $9.7 \%$ of the total assets of the previous year. In IPO year and after 1 year, Means of degree of CFO manipulation are respectively 0.015 and 0.008 . According to the data, we can make a preliminary judgment that there is an obvious upward CFO manipulation in the IPO company 1 year before the IPO year, and drops in the IPO year and 1 year after it.

Table 2 Descriptive Statistics for CFO Manipulating Degree

\begin{tabular}{|c|c|c|c|c|}
\hline Year & Mean value & $\mathrm{N}$ & $\begin{array}{c}\text { Standard } \\
\text { deviation }\end{array}$ & $\begin{array}{c}\text { The standard of } \\
\text { mean value misses }\end{array}$ \\
\hline $\mathrm{T}-1$ & .097035 & 696 & .1753911 & .0066578 \\
\hline $\mathrm{T}$ & .015138 & 696 & .2394663 & .0090900 \\
\hline $\mathrm{T}+1$ & .008429 & 696 & .1463303 & .0055546 \\
\hline
\end{tabular}

So the results showing above are significant? Then, we carry out paired $\mathrm{t}$ test between $\mathrm{T}-1, \mathrm{~T}$ and $\mathrm{T}-1$, test results are shown in Table 3 . Table 3 shows that $\mathrm{T}-1$ and $\mathrm{T}$ annual average difference is 0.081 , at $1 \%$ significance level significantly different from $0 ; \mathrm{T}-1$ and $\mathrm{T}+1$ annual average difference is 0.089 , at $1 \%$ significance level significantly different from $0 ; \mathrm{T}$ and $\mathrm{T}+1$ annual average difference is 0.006 , in the $1 \%$ level of significance is not significantly different from 0 , further testing revealed, at $10 \%$ significance level, annual average difference is not significant. Therefore, we believe that there is an obvious upward CFO manipulation in the IPO Company 1 year before the IPO year, and drops in the IPO year and 1 year after it significantly, thus the hypothesis 1 get proved.

\section{B. Regression Analysis for the Motivation of CFO Manipulation}

Analysis of the results is in Table 4, as it can be seen, the variance inflation factors (VIF) between the variables are far less than 10 , tolerance is much smaller than 0 , it means that serious multicollinearity does not exist between the variables. Due to the constant is significant at the 0.026 level, less than
0.05, so, we make use of standardized coefficients. For the matching motivation (PB), the coefficient of 0.165 , thus confirms the hypothesis 2, namely, IPO Company has the motivation to match with the profit by manipulating the $\mathrm{CFO}$, in order to conceal the earning management behavior of the company and we call that the motivation is matching motivation.

Table 3 Paired Samples T Test for CFO Manipulating Degree (99\%)

\begin{tabular}{|c|c|c|c|c|c|c|}
\hline Pairs & $\begin{array}{c}\text { Mean } \\
\text { value }\end{array}$ & $\begin{array}{c}\text { Standard } \\
\text { deviation }\end{array}$ & $\begin{array}{c}\text { Mean value } \\
\text { The standard } \\
\text { missing }\end{array}$ & $\mathrm{t}$ & $\mathrm{df}$ & $\begin{array}{c}\text { Sig. (one } \\
\text { pair) }\end{array}$ \\
\hline$(\mathrm{T}-1)-\mathrm{T}$ & .0818967 & .1932240 & .0073347 & 11.166 & 693 & $.000^{*}$ \\
\hline $\begin{array}{c}\mathrm{(T}-1)- \\
(\mathrm{T}+1)\end{array}$ & .0886055 & .2259170 & .0085757 & 10.332 & 693 & $.000^{*}$ \\
\hline $\mathrm{T}-(\mathrm{T}+1)$ & .0064956 & .2795294 & .0105955 & .613 & 693 & .540 \\
\hline
\end{tabular}

We think that the main reason for this phenomenon is the profit worship in Chinese stock market where for both issuers and investors, basic information that they used in valuation is earnings information, then the cash flow information; in the pricing of IPO, IPO companies have stronger motivation to carry out earning management. However, the cash flow information and accounting earnings information contrast, investors are easily found company earnings management behavior; therefore, in order to cover the company's earnings management behavior, and the company would have to manipulate the CFO.

The other two motivations at $5 \%$ significance level is not significant. Further studies showed in the $10 \%$ level of significance is not obvious. However, the coefficient of Year2006 is positive, indicating that, in year 2006 and after it, IPO company carry out positive manipulation to CFO. The coefficient of $\mathrm{PB} *$ Year2006 is negative, IPO company manipulating the CFO due to the "regulatory motivation", and partially abandoned "Matching motivation ", this is mainly because of the CSRC make a requirements in the absolute value CFO, the IPO company partly abandons the profit quality in order to meet the requirements.

Table 4 regression coefficient table (95\%)

\begin{tabular}{|c|c|c|c|c|c|}
\hline & $\beta$ & $\mathrm{t}$ & Sig. & Allowance & VIF \\
\hline (constant) & & -2.229 & .026 & & \\
\hline PB & .470 & 8.358 & .000 & .306 & 3.267 \\
\hline Year2006 & .008 & .169 & .866 & .411 & 2.431 \\
\hline PB*Year2006 & -.054 & -.853 & .394 & .238 & 4.199 \\
\hline ROA & .416 & 9.735 & .000 & .529 & 1.891 \\
\hline GRO & .035 & 1.046 & .296 & .852 & 1.174 \\
\hline DTA & -.091 & -2.149 & .032 & .541 & 1.850 \\
\hline LnA & .060 & 1.710 & .088 & .791 & 1.265 \\
\hline
\end{tabular}




\section{Conclusions}

Based on the research above, we can draw the following conclusions: (1) There is an obvious upward CFO manipulation in the IPO Company 1 year before the IPO year, and drops in the IPO year and 1 year after it significantly; (2) IPO Company has the motivation to match with the profit by manipulating the $\mathrm{CFO}$, in order to conceal the earning management behavior of the company, we call that the motivation is matching motivation ; (3)in 2006, the CSRC made a requirements in the absolute value $\mathrm{CFO}$, but still no evidence of significant support that the IPO company carry out CFO manipulation out of the "regulatory motivation".

The conclusion of the study can be partially explained the empty high issuing price in IPO market of China. At the same time, it also explains that the high quality of earning may come from the results of the manipulation $\mathrm{CFO}$ by the IPO Company. Thus, the methods of using the "CFO per share" compared with "Earning per share" to screening the accounting information will become more difficult.

\section{References}

[1] Burgstahler D, Dichew I. Earnings Management to Avoid Earnings Decreases and Losses. Journal of Accounting and Economic, 1997,Vol 24, NO.9: 99-126.

[2] Roychowdhury Sugata. Earnings Management through Real Activities Manipulation. Journal of Accounting and Economics, 2006, Vol 37, NO.5: 335-370.

[3] C.S.Agnes Cheng, Simon S.M. Yang. The Incremental Information Content of Earnings and Cash Flows from Operations Affected by Their Extremity. Journal of Business Finance \& Accounting, 2003,Vol 30, No.1-2: 73-89.

[4] Wu Liansheng, etc., what is the Degree of Manipulation of $\mathrm{CFO}_{-}$ Evidence from Chinese Stock Market. Financial Research, 2007 (3): 162-174.

[5] Chen Li. Empirical Study of the Manipulation of CFO in Chinese Listing Company. Finance and Economics Science, 2006 (4): 30-36.

[6] Wang Huacheng, etc., the usefulness of the Cash Flow Information Revealed by the Chinese Listing Company. Economic Theory and Economic Management, 2003 (10): 29-35. 